\title{
AVALIANDO A PRÉ-ESCOLA: UMA TRAJETÓRIA DE FORMAÇÃO DE PROFESSORAS*
}

ELISANDRA GirardelLi Godoi*

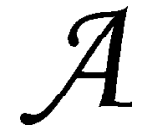

valiando a pré-escola, uma obra que acabou de ser lançada pela editora Autores Associados, aponta um novo olhar em relação à avaliação, onde a criança deixa de ser o alvo desse processo e o contexto educativo passa a ocupar o lugar central. Desse modo, este instrumento não é usado para medir, julgar, comparar e selecionar as crianças, mas, sim, como um mecanismo de reflexão e conhecimento por parte das professoras sobre a realidade e o trabalho que realizam.

Esta experiência denominada pesquisa-formação foi sendo construída e vivenciada em pré-escolas do município de Pistóia, na Itália, integrando pesquisadores da Universidade de Paiva e professoras da rede pública. $\mathrm{O}$ objetivo era proporcionar às professoras uma formação continuada que as levassem a refletir e analisar sua própria prática, favorecendo um crescimento de seu trabalho e o da escola como um todo.

Conhecer esta experiência foi possível devido à tradução do texto original em italiano, financiada pelo Laboratório de Observação e Estudos Descritivos (loed), da Faculdade de Educação da Unicamp, coordenado pelo Prof. Dr. Luiz Carlos de Freitas, que fez a revisão técnica do livro e escreveu o prefácio. Além desta participação, o traba-

\footnotetext{
* Resenha do livro organizado por E. Becchi \& A. Bondioli (Campinas: Autores Associados, 2003).

** Doutoranda da Faculdade de Educação da UNICAMP e professora do curso de Pedagogia em faculdade da rede privada. E-mail: elisandragodoi@hotmail.com
} 
lho contou com a contribuição da Profa $\operatorname{Dr}^{\mathrm{a}}$ Ana Lúcia Goulart de Faria, coordenadora do grupo de pesquisa de Educação Infantil da mesma faculdade, também fazendo a revisão técnica.

O livro é dividido em três partes, apresentando dois textos em cada, totalizando seis olhares sobre a proposta de trabalho que foi vivenciada em Pistóia. A discussão destaca esta experiência, não como um manual de técnicas e instrumentos de avaliação a serem seguidos, mas como um referencial que poderá servir de inspiração para pensarmos a avaliação dentro da realidade brasileira, uma vez que a nossa legislação prevê que a avaliação, neste momento da educação, tenha um sentido de acompanhamento do crescimento da criança e do trabalho pedagógico, sem o objetivo de promoção ou retenção.

No primeiro texto, Ferrari descreve o caminho percorrido na realização deste trabalho, apresentando a metodologia e os instrumentos que foram utilizados, bem como os sujeitos da pesquisa e a maneira como atuaram nesse processo. Ao relatar os procedimentos utilizados, a autora destaca: a observação do cotidiano educativo a partir de uma escala para observação e avaliaçãa das pré-escolas (Sovasi, tradução Italiana), baseada em um instrumento de pesquisa americano que foi adaptado e usado no contexto italiano e também uma grade de análise do dia-a-dia, ambos usados na coleta dos dados. Depois desse momento, o trabalho seguiu com discussóes coletivas dos dados e dos instrumentos aplicados, onde o sujeito envolvido atuava tanto como "objeto" de observação, quanto observador avaliador.

O segundo texto da primeira parte, escrito por Gariboldi, traz a descrição do cotidiano educativo de uma pré-escola, onde os observadores externos acompanharam um dia de trabalho em uma turma de crianças de quatro anos. A análise dos dados foi realizada a partir de cinco variáveis: espaço, participantes, atividades, agrupamentos e modalidades de gestão. O texto desperta interesse ao proporcionar ao leitor uma visão geral da dinâmica vivenciada pelos diversos atores sociais naquele espaço educativo.

A segunda parte do livro inicia-se com um texto de Bondioli apresentando e discutindo a importância da "gestão do envolvimento" no cotidiano educacional, onde afirma que a atenta regência por parte da professora no decorrer das experiências vivenciadas faz a diferença: “(...) é um dos aspectos comuns e mais interessantes das pré-escolas de Pistóia; e é também, na minha opinião, um dos aspectos que distinguem as escolas de qualidade" (p. 59). Além de apontar este aspecto como um elemento importante de qualidade, apresenta o exemplo de uma pré-escola onde esta 
prática se efetiva. A partir da descrição da entrada das crianças na instituição, é interessante observar como a professora conduz este momento, ou seja, como sua regência vai sendo construída envolvendo a criança nesse processo. É prazeroso para o leitor acompanhar a atuação da criança como um sujeito participativo no jogo social.

Analisando a segunda parte do livro, um outro texto de Gariboldi faz a descrição de uma atividade psicomotora realizada com um grupo de crianças de quatro anos, onde o objetivo, segundo a professora, era "movimentar-se brincando de cavalo". Assim, o autor apresenta ao leitor um pouco do cotidiano educativo em uma pré-escola de Pistóia por meio da descrição do desenvolvimento desta atividade.

Durante o episódio relatado, destacam-se as falas da professora e das crianças. É interessante observar que o papel da professora, durante este momento, foi de participante da experiência proposta, vivendo este momento junto com as crianças, interagindo na brincadeira e dando voz às mesmas. Quero destacar uma fala da autora que resume muito bem o que senti quando participei deste episódio como leitora: “(...) Uma pedagogia que não coloca a criança única e esquematicamente como objeto de uma programação adulta, mas que parte da escuta dos desejos, das fantasias e das idéias expressas por cada uma das crianças, sempre diferentes, para realizar atividades pensadas e construídas em conjunto" (p. 94). Uma pedagogia da Educação Infantil que é diferente da casa, do hospital e da escola, é uma experiência construída com a participação de três protagonistas: a criança, os educadores e a família.

O primeiro texto da terceira parte do livro, escrito por Livraghi, traz uma discussão sobre o olhar das professoras em relação ao trabalho que realizam e também da escola como um todo. Agora, é a percepção dos sujeitos e o reconhecimento de sua prática que foram descritos por meio da elaboração de documentos. Nesta elaboração, foi oferecido como suporte o uso de um questionário que abordava diversas áreas temáticas a serem analisadas, seguindo a estrutura dos instrumentos de pesquisa utilizados durante o projeto. A autora apresenta vários exemplos de depoimentos das professoras a respeito destas áreas, e é interessante observar as reflexôes que são apontadas por elas, mostrando um olhar crítico e sensível em relação à realidade em que atuam e os resultados de um processo de formação que reuniu diversos atores sociais.

Concluindo esta obra, Becchi escreve o último texto: "Por uma pedagogia do bom gosto", apontando que o trabalho das pré-escolas de Pistóia transcorre num sentido de movimento, onde os atores vivem papéis e experiências reais e imaginárias, como uma representação teatral. 
$\mathrm{Na}$ construção deste espetáculo, é no cotidiano educativo que aparece a possibilidade de trocas, onde o adulto e a criança poderão experimentar papéis e experiências diferentes. O que é mais significativo e semelhante a esta representação teatral, segundo a autora, é o fato do trabalho pedagógico também ter um final. "(...) uma pedagogia em que era dada proeminência para a completude, em que nos preocupávamos para que as coisas não fossem interrompidas, mas completadas e para que fossem dados grande importância, expressão e valor exemplar àquilo que - objeto ou evento - fosse obtido" (p. 127). Assim, a prática que se construía não tinha a intenção de satisfazer os prazeres dos espectadores, mas dos atores que a vivenciavam, ficando claro que a experiência de Educação Infantil italiana reconhece a criança enquanto sujeito de direitos, produtor de cultura, portador de história e como um ator fundamental neste contexto.

A grande preocupação apontada no final do texto é em relação ao futuro destas experiências, ou seja, sua manutenção para que não sejam esvaziadas.

Este livro traz uma contribuição significativa para o campo da avaliação e para a área de Educação Infantil, uma vez que poucos estudos enfocando este tema, neste momento da educação das crianças, foram realizados. Ao conhecermos esta experiência, poderemos pensar em novos referenciais de avaliação para o cuidado e educação das crianças pequenas, também aqui no Brasil, enquanto primeira etapa da Educação Básica, sem antecipar a escolarização do Ensino Fundamental.

Este livro não pode deixar de ser lido, pois provocará um novo debate na área. 